\title{
After the first 32 years - new deal in Hungarian income taxation
}

\section{Након прве 32 године - нови приступ у опорезивању дохотка у Мађарској}

\author{
Mária Lakatos* \\ Eötvös Loránd University, Institute of Business Economics, Budapest, Hungary, \\ lakatos.maria@gti.elte.hu \\ Éva Karai \\ Eötvös Loránd University, Institute of Business Economics, Budapest, Hungary, \\ karai@gti.elte.hu
}

\begin{abstract}
Nowadays, few experts or politicians look back to the 80 s, the post-communist countries present their results after the transition to a market economy. But, in the 1980s, Hungary was the first of the socialist countries to launch major reforms, and within that, the financial system was reformed. The conversion of the banking and the insurance system started at that time, parallel with the Németh government fundamentally overturned the tax system and laid the foundations of today's modern tax system in both of direct and indirect taxation. Our study reviews the period that has been pasted from 1988 till the present time. One of the main aims of this work is to highlight some basic features in the Hungarian tax system, which differs from that of the OECD countries. The theoretical correlations deriving from the differences, however, reflect on the restrictions of the Hungarian system. We emphasizes only one question, what is the link between government tax policy implemented in tax legislation and the behavior of taxpayers.
\end{abstract}

Keywords: economic policy, reform, taxation, social system

JEL classification: H5, H11, H21, H55

Сажетак: У данашње време, мало стручњака или политичара осврће се на осамдесете године прошлог века, а посткомунистичке земље представљају своје резултате након преласка на тржишну економију. Мађарска је осамдесетих година прошлог века прва од социјалистичких земаља покренула велике реформе, а у оквиру њих покренута је и реформа финнансијског система. Тада је започета конверзија банкарског и система осигурања, паралелно са Неметовом владом, која је у основи поставила темеље данашњег модерног пореског система, како у директном тако и у индиректном опорезивању. Наша студија анализира период од 1988. до данас. Један од главних циљева овог рада је истицање неких основних карактеристика пореског система у Мађарској, који се разликује од оног у земљама ОЕЦД-а. Теоријски, корелације које произилазе из разлика одражавају се на ограничења мађарског система. У раду је истакнуто само једно питање које се односи на истраживање везе између државне пореске политике која се спроводи у пореском законодавству и понашања пореских обвезника.

Кључне речи: економска политика, реформа, опорезивање, социјални систем JEЛ класификација: H5, H11, Н21, Н55 


\section{Introduction}

The aim of the study is to present what steps Hungarian economic policy has taken to change the tax system, what goals it has set, which ones have been met, and where the shortcomings of the current system have been revealed. Tax policy as an instrument of economic policy has played an important role primarily in guaranteeing revenues: it can hardly be interpreted in itself; it always appears as part of fiscal policy, subordinate to it. That is why tax laws are always linked to the fulfilment of certain economic policy objectives, but it is not entirely clear how the behavior of taxpayers and their response to individual changes can or should be taken into account.

Although the theory of taxation discusses each type of tax extremely extensively, analyzing the different tax instruments, there is no clear answer as to when which type of tax system can be considered optimal. The 1988 Hungarian tax reform is one of the large-scale experiments. It was clear already at the end of the 1980s that opening the economy required a transparent internal price system, an income policy that can be measured and influenced through indirect instruments and definitely a value added type taxation system that is used in the EU. In addition, it was also time to reform the whole tax administration procedure. Once the necessary political decisions had been made, the tax reform was worked out in order to introduce a unified, legally regulated and normative taxation system as well as to implement public burden sharing that is more just in social terms and that makes the income transparent and taxes it at its very source. In return, however, it promised a bigger say in the re-distribution of public funds. The analysis of the changes in the past 30 years is deficient; the emphasis was generally laid only on the size of tax revenues, on analyzing the current situation of the state budget and the impacts of tax allowances.

\section{Theoretical background}

The current tax policy of a country is always one of the elements of the fulfilment of short-term and long-term priorities defined in the economic policy, which plays an extremely important role in guaranteeing revenues. The tax system is part of the current fiscal policy, which must serve the designated goals of the given period, mainly by generating revenues. After World War II, after a major change in economic policy, including the role of the state budget after the 1929 world crisis, the budget took on counter-cyclical, demand-stimulating tasks. In market economies, the role of the state in achieving community goals has become more and more important, such as raising general welfare, stimulating economic growth, reducing unemployment, creating social security, and introducing a general pension insurance system. (Stiglitz, 2002) These tasks could only be achieved by steadily increasing the share of centralized income in GDP (Oates, 1985) and (Estevez, 2020).

In developed states, expenditures and subsidies financing the growing role of the state, including those related to social security, necessarily multiplied, and this was, of 
course, covered by tax revenues (Kalaš et al., 2018a; Kalaš et al., 2018b). This was covered by GDP during the period of sustained economic activity until the 1980s, when world GDP growth averaged around 2\% per year between the Napoleonic Wars and World War II, but has grown steadily by an average of $4 \%$ over the last half century. Thus, the value of the gross domestic product produced year by year increased to a previously unimaginable size (Kádár, 2000). The budget centralized and redistributed an increasing share of the generated income, creating the institutional system necessary for social security. From the 1980s onwards, however, economic policy was logically strongly imbued with elements of fiscal policy, where the emphasis also changed, as the growing role of the state also created a persistent budget deficit.

Therefore, ensuring a balance in state budget, and finding a way to do so, has become a fundamental issue. These exogenous constraints have also played a role in the generalization of taxation and, at the same time, have provided a strong incentive to examine more closely the mechanism of action of taxation at both the macro and micro levels.

Thus, the development of taxation was also shaped by the external factors determining economic policy:

- $\quad$ growing demand for social benefits

- the growing need for funding due to the extension, generalization and continuous expansion of benefits

the need to finance the budget deficit due to public overspending.

(Although the budget is not a general feature of the finances of advanced economies, they are a problem to be solved from time to time. Even without a deficit, the constant demand for revenue means a demand for tax increases.)

In this system, there is an increasingly urgent need for the state to increase revenues, which has prioritized taxation as a tool. As a natural consequence of this, it was not possible to define an independent tax policy, as the given economic policy expectations always determined the revenue needs, and the applied tax system was designed and modified accordingly (Hetényi, 2004).

While one of the tasks of the tax system is strongly linked to fiscal policy, it has to perform other important functions, including the allocation of produced goods, which is a matter of free market competition and competitiveness, and the redistribution of produced goods, which makes tax and social policy links (Atkinson, 2015).

However, the traditional roles of the state and state power have been questioned since the 1990s: through global companies, the former nation-state borders are blurred, economic policy and, within this, fiscal and tax policy find themselves facing a strong determination. Economic policy, and in particular tax policy, should serve a new kind of 
growth model and, accordingly, a different economic model, of which, however, only empirical facts are available for the time being (Veress, 2004). At the same time, globalization, which means the re-emergence of economic liberalization at the economic policy level, combined with a completely new phenomenon, the merger of financial management and computer-telecommunications, has accelerated economic and decisionmaking processes unimaginably, making tax databases accessible - and linked the economic and management processes and regulatory mechanisms of each country (Kramer et., 2016). Globalization has thus given a new field to tax policy, which previously traditionally remained within the framework of the nation-state (Urban et al., 2019).

In this situation, taxation is not merely an instrument of national economic policy, but an element of the functioning of the international economic community, which must guarantee competitive neutrality above national levels while maintaining its allocation and distributional functions within the nation state, writes Alan Peacock in his study of tax competition (Peacock 1997) and (Forte \& Peacock 1981). Andreas Haufler, who argues that small, open economies are forced to keep corporate tax rates low, otherwise they will not be able to compete with large economies (Haufler, 2001).

\section{Methodology}

In our research, we used the tax acts published since 1988, which show the annual changes in personal income, corporate taxation.

The source of the statistical data was on the one hand also the data series accepted in the financial statements, and on the other hand we analyzed the processed data of the tax returns compiled by the National Tax and Customs Administration from 1994 onwards. For the period before 1994, we reviewed the internal statistics of the Ministry of Finance, in 1994 indicating the limitations of the comparison. The data series for each year also may differ depending on when they were published, but the differences modified the previous ones by a tenth of a percent, so where possible, we indicated the time of publication of the data series.

\section{Tax reform from 1988}

\subsection{The first period - tax reform in 1988}

The regulations before 1988 treated the incomes of the population deriving from various sources and acquired under various titles in a very different manner, therefore, it could not provide for public burden sharing proportionate with the size of income. Apart from this, the rate of taxes payable by the private persons was disproportionately lower than that of companies, which made it necessary to replace the wageproportionate corporate taxes with a uniform income tax system (Antal, 2004).

Basically, the personal income tax system merged the income categories that were earlier differentiated under various legal titles, and also extended the scope of the tax to the - formerly tax-free - interest on savings that people held at financial institutions as well as to the interest on bonds traded on the securities market at that 
time; however, the fragmentation that prevailed during the period before introducing the personal income tax also remained to stay after the reform of 1988. The personal income tax launched from 1988 had the following features (Ékes, 1997).

Obligatory consolidation was ordered for most income sources, and the tax obligation had to be assessed according to a progressive tax scale. However, separately taxed incomes did not pertain to the 11-class progressive tax scale but linear tax withholding tax was paid, e.g. interest, dividend incomes.

Private entrepreneurs were subject to a special "two-channel" taxation system. The point was that private entrepreneurs and partnerships paid $25 \%$ entrepreneurial tax on their business profit, while the amount of profit used for personal purposes was subject to personal income tax. As can be seen, the population became the main carrier of burdens already in this early stage (Magyar Közlöny, 1986).

Table 1: Revenues of the state budget according to main sources (in \%)

\begin{tabular}{|l|c|c|c|c|c|c|c|}
\hline Year & 1987 & 1988 & 1989 & 1990 & 1991 & 1992 & 1993 \\
\hline $\begin{array}{l}\text { Business } \\
\text { organizations }\end{array}$ & 63.2 & 55.5 & 48.2 & 40.6 & 30.9 & 26.3 & 22.9 \\
\hline Population & 25.0 & 32.2 & 34.8 & 36.9 & 38.9 & 39.3 & 38.8 \\
\hline Other & 11.8 & 13.3 & 17.0 & 30.2 & 32.3 & 34.4 & 38.3 \\
\hline Total: & 100 & 100 & 100 & 100 & 100 & 100 & 100 \\
\hline
\end{tabular}

Source: Authors research based on Ministry of Finance Data 1994

The direct tax burdens of the population went up from $9 \%$ (in 1988) to $17 \%$ in the percentage of taxable incomes, while the average tax on incomes moved between 5 and $15 \%$. The indirect tax burdens on the population were not assessed in that period by referring to the fact that small ventures and private entrepreneurs not subject to VAT were also considered as final consumers, but the three-rate VAT increased the tax burden on the population by $10 \%$ on average- said the Ministry of Finance in its inner report in 2001 (Ministry of Finance, 2001).

In a single year, the state budget gained a new income source at a rate that was inconceivable before, even if the state budget refunded to the companies a certain part of the grossed up wages (companies extended the wages in order to protect employees from losses). As is shown by the statistics reflecting the revenues of the first six years and the year preceding the year of introduction, the highest growth of revenues came from personal income tax (also at net present value), while the VAT increased at a rate falling behind the inflation, and the amount received from corporate taxation became lower.

The primary targets were met at the level of the state budget. The following general conclusions can be drawn from the figures: 
- the business organizations paid an amount that kept decreasing both at nominal value and at its rate compared to the revenues of the state budget (growth was only recorded with customs and import payments);

- $\quad$ personal income tax payments by the population showed a dynamic increase, the rate of personal income tax in the state budget revenues exceeded 10\% (from the 1990s);

- within the key tax types, there was a shift towards consumption-type taxes;

- the rate of state budget centralization did not decrease despite the original concepts, thus the state budget basically determined the use of more than half of the GDP and it maintained its role in redistributing the revenues.

- However, the introduced tax system had certain features that needed correction almost immediately.

Applying many brackets in personal income taxation made a superfluously detailed difference between various population groups and the upper $60 \%$ proved to be extreme progression.

- Even at that time, tax collection and control was narrowed down only to processing about 4 million personal income tax declarations and to ventures declaring the highest income.

- Therefore, the reported cost statement deductions became impossible to control (this led to the special Hungarian new verb, (term) "elköltségelés", (over-expensed) i.e. collecting cost invoices) and revenue control was also reduced to the obligatory data submission that was ordered for companies.

Thus, the introduced tax system clearly deteriorated the situation of the population, which moderated the burden on companies in absolute terms and the revenues of the state budget went up to an unprecedented extent. The size of income from personal income tax induced the government to reduce the $100 \%$ share promised to municipalities first to $50 \%$ within a year, and this decision brought the newly shaping local municipalities and the whole municipality system into a tough position. Analyzing the situation of municipalities, Gábor Gulácsi (1993) concluded that - as a secondary impact - re-transferring personal income tax to municipalities on a territorial basis further increased the disadvantage of poor regions with little, or quickly dissolving industrial and agricultural production structure.

However, the personal income tax structure integrated further inequalities into the system. Public burden sharing was not proportionate with the incomes as different taxes (according to source) were assigned to consolidated and unconsolidated incomes.

Despite this, the personal income tax system is one of the success stories of the economic policy of the Németh government, as it created a basic condition for European integration, provided the opportunity to calculate labour price according to the real market relations and, parallel with this, it restored the obligation of the citizens 
to share the public burden. On the other hand, it placed a significant part of the state budget incomes onto a stable base.

In the next part of our study we are only analyzing the changes in the personal income tax system from the above introduced starting point.

Table 2. Tax changes 1989-2015

\begin{tabular}{|c|c|c|c|c|c|c|}
\hline $\begin{array}{l}\text { Main tax } \\
\text { elements }\end{array}$ & 1988 & 1989-1994 & 1995-1998 & 1998-2002 & $2002-2010$ & 2011-2015 \\
\hline Tax rates & $0-60 \%$ & $0-56 \%$ & $\begin{array}{l}\text { the } 0 \% \text { rate } \\
\text { was } \\
\text { terminated, } \\
20-48 \% \text {, then } \\
20-42 \%\end{array}$ & $20-40 \%$ & $\begin{array}{l}2002-2006: \\
18-38 \% \\
2004-2010 \\
18-36 \%\end{array}$ & 16, then $15 \%$ \\
\hline Tax scale & 11 brackets & 6 brackets & 6 brackets & 3 brackets & $\begin{array}{l}3 \text { brackets } \\
\text { until } 2004 \text {, } \\
\text { then two } \\
\text { brackets }\end{array}$ & 1 bracket \\
\hline $\begin{array}{l}\text { Tax free } \\
\text { limit }\end{array}$ & 48,000 & $\begin{array}{l}110,000 \\
\text { forints }\end{array}$ & $\begin{array}{l}\text { tax credit for } \\
\text { employees }\end{array}$ & none & $\begin{array}{l}\text { minimum } \\
\text { wage is tax } \\
\text { free with tax } \\
\text { credit }\end{array}$ & none \\
\hline Allowance & $\begin{array}{l}\text { allowance for } \\
\text { employees, } \\
\text { allowance for } \\
\text { children, } \\
\text { tax } \\
\text { exemption } \\
\text { for meal } \\
\text { contribution } \\
\text { at work. } \\
\text { tax } \\
\text { allowance for } \\
\text { intellectual } \\
\text { work }\end{array}$ & same & $\begin{array}{l}\text { the former } \\
\text { allowances } \\
\text { were } \\
\text { terminated }\end{array}$ & $\begin{array}{l}\text { allowance for } \\
\text { children, } \\
\text { allowance for } \\
\text { paying } \\
\text { interest on } \\
\text { mortgage } \\
\text { credit, } \\
\text { allowance for } \\
\text { tuition }\end{array}$ & $\begin{array}{l}\text { the former } \\
\text { allowances } \\
\text { were } \\
\text { reduced } \\
\text { between } \\
2002 \text { and } \\
2006 \text { and } \\
\text { totally } \\
\text { terminated } \\
\text { from } 2006\end{array}$ & $\begin{array}{l}\text { family } \\
\text { allowance, } \\
\text { family } \\
\text { contribution } \\
\text { allowance, } \\
\text { allowance for } \\
\text { married } \\
\text { couples, } \\
\text { allowance for } \\
\text { handicapped } \\
\text { people } \\
\text { Cafeteria - the } \\
\text { groups } \\
\text { receiving } \\
\text { allowance }\end{array}$ \\
\hline
\end{tabular}




\begin{tabular}{|c|c|c|c|c|c|c|}
\hline & & & & & & $\begin{array}{l}\text { keep } \\
\text { narrowing, its } \\
\text { charges near } \\
\text { the wage } \\
\text { charges }\end{array}$ \\
\hline $\begin{array}{l}\text { Movable - } \\
\text { immovable } \\
\text { property }\end{array}$ & $\begin{array}{l}\text { income to be } \\
\text { combined }\end{array}$ & same & $\begin{array}{l}\text { ranked as } \\
\text { income to be } \\
\text { taxed } \\
\text { separately }\end{array}$ & same & same & same \\
\hline $\begin{array}{l}\text { Income } \\
\text { taxed } \\
\text { separately }\end{array}$ & $20 \%$ & $0 / 10 / 20 \%$ & $\begin{array}{l}20 \%, \\
\text { tax credit for } \\
\text { stock } \\
\text { exchange } \\
\text { investments } \\
\text { (tax } \\
\text { exemption), } \\
\text { initially } \\
\text { without } \\
\text { limitation. }\end{array}$ & $20 \%$ & $20 \%$ & 16 , then $15 \%$ \\
\hline $\begin{array}{l}\text { Employee } \\
\text { contribution }\end{array}$ & $\begin{array}{l}\text { reduced the } \\
\text { tax base }\end{array}$ & $\begin{array}{l}\text { reduced } \\
\text { the tax } \\
\text { base }\end{array}$ & $\begin{array}{l}\text { did not } \\
\text { reduce the } \\
\text { tax base. } \\
\text { The group of } \\
\text { incomes } \\
\text { subject to } \\
\text { social } \\
\text { insurance } \\
\text { contribution } \\
\text { was } \\
\text { extended, } \\
\text { also covering } \\
\text { activities } \\
\text { already } \\
\text { subject to } \\
\text { copyright } \\
\text { protection. }\end{array}$ & $\begin{array}{l}\text { it once again } \\
\text { partially } \\
\text { reduced the } \\
\text { tax base. } \\
\text { The } \\
\text { employer } \\
\text { contribution } \\
\text { was reduced } \\
\text { by } 10 \% \text {. } \\
\text { (from } 39 \text { to } \\
29 \% \text {.) }\end{array}$ & $\begin{array}{l}\text { it once again } \\
\text { did not } \\
\text { reduce the } \\
\text { tax base. } \\
\text { Solidarity } \\
\text { contribution } \\
\text { above a } \\
\text { gross annual } \\
\text { wage of HUF } \\
6,748,850\end{array}$ & $\begin{array}{l}\text { cannot be } \\
\text { deducted from } \\
\text { the tax base, } \\
\text { its rate is } \\
17+1.5 \%\end{array}$ \\
\hline Investments & $20 \%$ & $\begin{array}{l}\text { returns on } \\
\text { state } \\
\text { securities }\end{array}$ & $\begin{array}{l}\text { the tax on } \\
\text { returns on } \\
\text { state } \\
\text { securities }\end{array}$ & $\begin{array}{l}\text { the } 20 \% \text { tax } \\
\text { on exchange } \\
\text { gains also } \\
\text { covered the }\end{array}$ & $\begin{array}{l}\text { the returns } \\
\text { on stock } \\
\text { exchange } \\
\text { investments }\end{array}$ & $\begin{array}{l}16, \text { then } 15 \% \\
0 \% \text { on } \\
\text { amounts kept }\end{array}$ \\
\hline
\end{tabular}




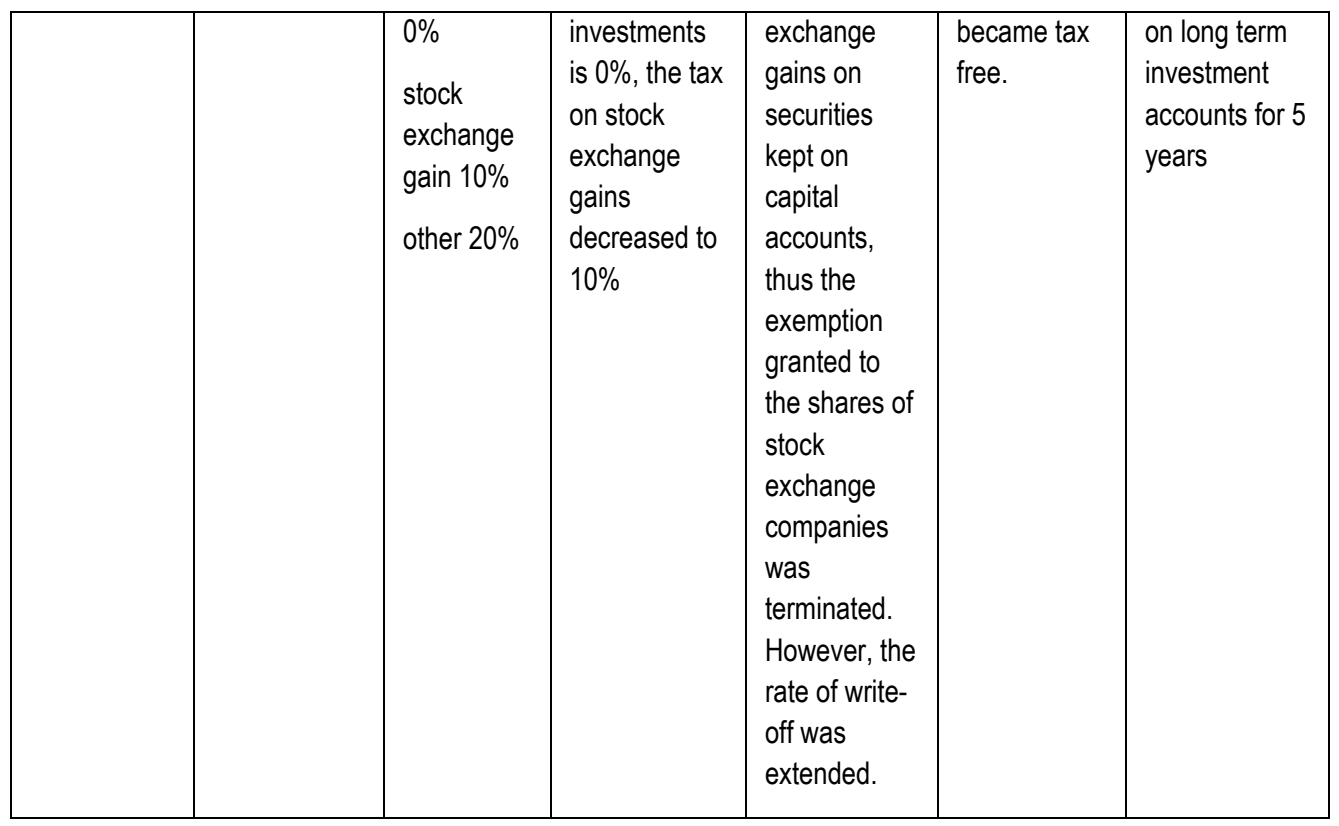

Source: the authors' research from the Hungarian Personal Income Tax Act

\subsection{The second period - changes 1989-1994}

The two years remaining until the change of regime and the next four years produced no major changes, only minor corrections in terms of taxation policy. By 1994, however, the state budget deficit - where state debts represented an especially high rate - could no longer be managed due to the complex effect of the earlier inconceivable rate of economic transformation, due to the reorganization of the total production chain and, of course, due to the transformation crisis caused by the loss of the traditional markets.

The picture is even more sophisticated if we look at the transformation from the viewpoint of the trend in the number of potential tax-payers. Between 1989 and 1995, the restriction on the market entry by private businesses ceased to exist when the transformation act, the company act and the cooperative act were modified and adopted as well as companies and ventures could be founded and launched on a subjective right. However, an unprecedented wave of liquidation swept all over the whole economy. As a result of these two impacts the former employee data went down from 4.8 million to 3.7 million, while the number of entrepreneurial organizations increased from 400,000 to almost 1 million. This means that $25 \%$ of the former wage-earners disappeared and were on the unemployment benefit, while the number of enterprises increased by 2.5 times. It was evident already at that time that the number of 
entrepreneurs grew out of constraint, the legal obligations of contracting were selected for protection against unemployment, but the question was whether they could satisfy any of their obligations.

The Personal Income Tax Act merely followed the changes, e.g. the tax class limits were increased to counterbalance the above-30\% inflation rate but this could not prevent the higher burden as a result of the inflation.

As it can be seen, the characteristic features of the current situation evolved during this period. Accordingly, in the surveyed period:

- the Hungarian taxpayers did not pay significantly more than the taxpayers in Western Europe:

- the division of incomes remained to stay but separately taxed incomes started to grow and they paid less and less tax:

- taxpayers are divided to employees, who cannot avoid taxes so they take a higher share in the burden, and to private entrepreneurs who adapt to the tax changes extremely flexibly, they form the biggest group and their behaviour basically determines the tax revenues.

\subsection{The impact of the Bokros package on the tax system}

The change in a taxation policy is not determined primarily by the increase or the moderation of the tax brackets, by the change of the tax rate or even by the restructured allowances. The changes can be classified according to the change of the legal regulatory environment termed by Brennan and Buchanan (1980) as the tax constitution, how the tax constitution guarantees the former allowances either in a more moderate form or even by granting them to other groups, or - on the contrary - what acquired rights are withdrawn or granted (Brennan, 1993). From this viewpoint, basic importance was carried by the programme hallmarked with the name of Lajos Bokros that the government launched on 12 March 1995. This study covers only and exclusively the aspects of the programme related to taxation policy and personal income tax together with the related revenue figures as evaluating this programme is not the task of this study. The economic policy goal of narrowing the demand, reducing state expenditure and increasing revenues was planned to be achieved by modifying the next tax act, which otherwise played a subordinate role in the changes.

Although the Constitutional Court decided in 1995 to repeal a significant part of the Bokros package, no change was made to the modification of the tax laws, except for accident contribution payment, as the constitutional rights were not affected (Complex CD Jogtár, 2006). The Hungarian constitution specifies tax payment as a contribution to the public burden and a unilateral obligation of the citizens without any counter-service, and the spirit of this provision was not violated by the Bokros package. The austerity measures were enacted through two years after the forced break, 
and the then government regarded it as a success that they managed to reduce the deficit of the balance of payments quickly and at a high rate also in an international comparison. This, in itself, restored the confidence of the international money markets and it was possible to finance the deficit that remained to stay and was soon reproduced in an unchanged form. Some reshuffle could be observed in the second half of the 4year political cycle, primarily in the modification of the allowances, tax credits and tax brackets, but basically this did not change the nature of the tax system.

Analyzing the listed changes, it is evident that primarily pensioners, employees and families with children got into a worse situation. If we do not look at the issue from a social political aspect but from the viewpoint of almost 400,000 private entrepreneurs and almost one million businesses in total, we can spot the following differences between the two types of tax system:

The deductibility of social insurance contribution was cancelled, which raised the costs both for private businesses and partnerships. The termination of the 0 rate income class excluded private entrepreneurs and the owner-managers of partnerships (internal members of limited partnerships - managing directors) from the circle of exemption as tax credits were only granted to the employee status. This means that this group was not given exemption even if they earned the minimum wage. The former HUF 100,000 tax base reducing allowance for activities subject to copyright changed for a tax allowance of HUF 50,000, which definitely reduced the real value of the allowance, depending on the income limit. Narrowing the scope of activities subject to copyright and making these incomes subject to contribution payment was disadvantageous for about 170,000 taxpayers.

We can observe a strong preference to the accumulation of wealth and with regard to taxing returns on deposits and state securities investments ( 0 rate) due to the general interest in increasing investments and with regard to reducing the stock exchange gains to $10 \%$ in 1995 and 1996.

As a result of the actions of the Bokros package, a personal income tax system was created - basically differing from the tax reform in 1988 - that focused on efficiency instead of the previously preferred aspects of equity and fairness, last but not least also through the increasing rate of control. This tax system was much more able to increase tax revenues from inflationary tax forints without any further change, as its introduction was accompanied with a higher than expected $12 \%$ price increase, which automatically increased payments not only at a nominal but also at a real value, while freezing the tax allowances, namely because the tax-reducing items do not follow the progression, and the impact is totally different if a certain $\%$ of the part taxed with the marginal tax rate is deducted from the annual income without any limitation above which grows together with the inflation - compared to deducting from the payable tax a maximum amount that is limited from above. 
As a result, a different personal income tax system was set up, which practically ignored the social aspects, leaving the enforcement of the principles of equity and fairness to social policy; it was strongly differentiated according to the sources of incomes and expressly preferred capital incomes while it connected income tax with social insurance deductions also over and above wages. This feature was further strengthened not only by the a.m. extension of the contribution base but also by the rule which made it compulsory to pay full social insurance contribution for all other legal relationships in the case of employment below 36 hours a week, i.e. some part-time entrepreneurs paid twice. This means that the obligation to pay taxes and contributions were closely related to each other.

\subsection{Changes in the taxation system 1998-2002}

The economic policy reorganisation accompanying the governmental change was in favour of growth instead of monetary and fiscal restriction and creating balance, and it had a definite concept on the groups where it intended to strengthen the horizontal and equity aspects and where to create the socially useful family model through indirect interest in taxation.

Family support reached its peak in 2002, while HUF 71 bn was available for tax credit, and the government supported families with children with a tax revenue dropout of HUF 76 bn. We cannot talk either about large-scale change or reform despite the simplified tax scale and re-positioned allowances within the population groups. However, from 1998, the social insurance contribution paid by employers was reduced radically, by 10 percentage points. The rate of deduction went down from the former $39 \%$ to $29 \%$, claiming that no new jobs were created due to high contributions. The $10 \%$ reduction was counterbalanced by the increasing health contributions only partially, raising the effective rate of health insurance contribution by $1.06-1.91 \%$ on average (Szigeti, 2007).

The minimum wage went up from HUF 25,000 to HUF 40,000, which was mainly disadvantageous for entrepreneurs. Interestingly enough, the increase was not accompanied with higher unemployment, which is a relationship accepted in the professional literature. Moreover, the unemployment rate reduced under the conditions of the general boom. (Varian, 2014) Increasing the minimum wage also meant a higher contribution base, finally the amount received from social insurance contributions did not reduce because growth remained the joint impact of lower employer deduction and the parallel minimum wage increase. Therefore, the Orbán government basically reorganized the allowances, which did not change on the whole; the emphasis was laid on large, middle class families with children and with earning capacity rather than supporting those who were most in need in social terms. (What is more, family allowances and family support could only be received for children who had a school attendance certificate.) However, the government strongly reduced the contributions but did not touch the benefits that were financed from contributions. 
During the four years, the personal income tax revenues significantly increased, by HUF 155.7 bn, i.e. $24 \%$ on average, the amounts from social insurance contributions also went up, though slightly, but no major change was recorded either in VAT or in corporate tax revenues. At the same time, there were much more private entrepreneurs who did not only declare but also paid taxes and this growth can partly be explained by the impact of high tax exemptions as well.

The number of taxpayer employees also showed an increasing trend - another partial impact was the number of those who found work due to the reducing unemployment rate and the minimum wage increase in 2001, which was not followed by tax credit growth, therefore tax also had to be paid on income in the lowest class. The effective personal income tax rate was the highest in this period. At the same time, the growth of revenues was much higher than in the former years, which implies a change in the taxpayer behaviour, they voluntarily stepped back to the legal taxpayer circle. Changes at a similar rate but with a different sign took place over the next four years although the tax burden was lowered in all the three tax types, but in different years.

\subsection{Changes in the taxation system 2002-2010}

After the government reorganization, the 100-day programme implemented the partially tax political actions promised at the elections, and the resignation of Péter Medgyessy was followed by another austerity package. However, it became evident from the middle of the period that the number of taxpayers dramatically decreased due to the financial crisis, therefore, not only the framework of personal income tax was burst by the increasing budgetary deficit - which was counter-balanced by introducing a special solidarity contribution - but the VAT on basic consumer articles also increased. The allowances kept reducing, the benefits introduced until 2002 were finally terminated, the Sulinet programme - meant to help integration with the digital world - disappeared and the tax exemption of tuition was also terminated. Both the nominal value of personal income tax revenues and the number of taxpayers kept decreasing in this period. 
Figure 1 Growth of personal income tax revenues calculated at current price, 1995-2015

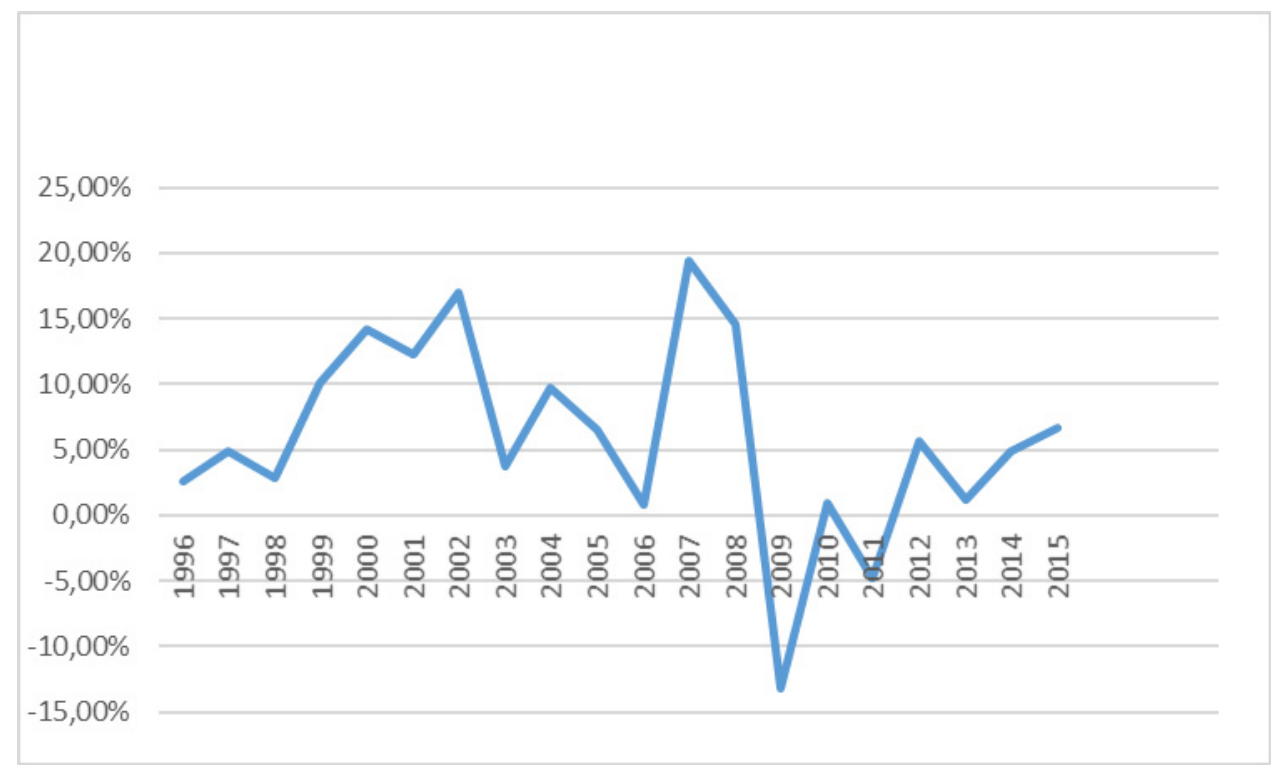

Source:Hungarian Tax Authority statistic 1995-2015, archives

\section{Switch to a single rate tax system - 2010}

The figures already showed in 2010 that the Hungarian personal income tax system could not stay within the former framework: neither the number of taxpayers nor the increasing tax burden paid by them reached the minimum level required for financing the state budget, and in the meantime there were no incentives or social sensitivity either (György, 2016).

Although the idea of the linear tax system - based on the single rate (19\%) Slovakian system - was mentioned several times during the former years, this was manifested at the level of the official taxation policy in the summer of 2010 in the form of the first economic action plan, whereby the government promised to introduce the single-key income tax, eased with family elements, within two years and to terminate tax credits (MSZOSZ,2012). Accordingly, the personal income tax system was basically transformed, the two rates were terminated and replaced first by the $16 \%$, then the $15 \%$ flat rate.

The former system of allowances, which was strongly divided earlier and mainly preferred consumption, was also terminated and replaced by the family tax allowance mainly preferring families with two or more children and from 2014 by the family contribution allowance that extended the family tax allowance and also covered the 
poorest families. In addition, allowance is/was granted to young couples and to people living with handicap, while the tax allowance on insurance was practically terminated and the tax policy does not give preference to IT consumption, either. The minimum wage was raised significantly - and once its tax exemption was terminated - the number of actual taxpayers and the per capita tax revenues considerably increased and, of course, the state budget could also expect higher revenues from the population. In the meantime, however, there was a basic reshuffle on the labour market, the former $10 \%$ unemployment rate went down below 4\%, which further increased the number of taxpayers and the size of per capita tax, which still failed to reach the level of 2004 at nominal value.

Table 3: Number of taxpayers and per capita tax in 2002-2015 (nominal value)

\begin{tabular}{|l|l|l|l|l|l|l|l|l|l|l|}
\hline Year & 2002 & 2003 & 2004 & 2005 & 2006 & 2011 & 2012 & 2013 & 2014 & 2015 \\
\hline $\begin{array}{l}\text { Num } \\
\text { ber of } \\
\text { taxpa } \\
\text { yers }\end{array}$ & 27,860, & $\begin{array}{l}3,220, \\
438\end{array}$ & $\begin{array}{l}3,079, \\
517\end{array}$ & $\begin{array}{l}3,025, \\
639\end{array}$ & $\begin{array}{l}3,452, \\
148\end{array}$ & $\begin{array}{l}3,343, \\
260\end{array}$ & $\begin{array}{l}4,000, \\
162\end{array}$ & $\begin{array}{l}4,009, \\
937\end{array}$ & $\begin{array}{l}4,111, \\
444\end{array}$ & $\begin{array}{l}4,165, \\
995\end{array}$ \\
\hline $\begin{array}{l}\text { Per } \\
\text { capita } \\
\text { tax }\end{array}$ & 304 & 372 & 400 & 441 & 431 & 323 & 339 & 329 & 349 & 373 \\
\hline
\end{tabular}

Source: Authors research

\section{Conclusion}

As it can be seen, extremely large changes took place every four years on average, in harmony with the political cycles, but the impact of various tax changes should mainly be measured through the reactions of the citizens. An appropriate indicator is the trend in the number of taxpayers as the taxpayers typically pay or do not pay or dodge taxes if they feel that the give and take is not fair and they pay a too high price for the public goods in return for the "service" they receive.

Table 3 also shows that the taxpayer behaviour is not necessarily determined by the size of the effective, per capita tax.

The trend in the number of taxpayers is not full, as the figures of annual tax declarations are no longer available. At the same time, from 1995, statistical data were supplied in the Eurostat database in the spirit of joining the European Union, the former statements were made on the basis of another methodology. For this reason, the change in tax revenues shows the change in annual payments by the population calculated at current price, thus reflecting the joint impact of the changes that took place and the "responses" given by the population.

The optimal tax policy is always the result of a compromise, where the taxpayers accept that they have to pay but the tax price paid for the public goods does not exceed the equitable and fair level. The progressive tax scale may not fully conform to the principle of solvency, as the collected tax largely depends on the payment willingness of certain 
taxpayer groups. This means that the selected tax system is basically qualified by the final result.

The periods following the change of the regime are separated from one another by the repeatedly dissolving financial balance and the related shifts of emphases, sometimes even within the same political cycles. The tax policy was given a subordinated role here, and sometimes vertical and sometimes horizontal equity was enforced, but only in a restricted way. For the most part, the main objectives focused on increasing tax revenues besides funds narrowing due to the grave deficit as well as - parallel with this and as a contrary effort - on guaranteeing an advantageous situation for foreign investors. The strengthening balance aspects after 1994 did not allow for a large scale reform of the tax system, the minor and larger adjustments guaranteed the fulfilment of the revenue plans in the short run, but the deadline for decisions strongly narrowed down due to the political rotation and the decisions always focused on the next year's tax revenues rather than on a tax base to be formed four years later.

During the first seven years after the tax reform, the system - including all the three main tax types - kept its original features reflecting certain social policy elements, laying a lower tax burden on groups with low income in terms of both personal income tax and VAT. These features gradually disappeared after the correction in 1995, the allowances and benefits promoting the enforcement of social policy were removed from the personal income tax system and then from the VAT system. The tax burden was gradually transferred onto people with average wage. The increasing budgetary deficit followed by the financial crisis in 2008 also buried the former personal income tax system, and the system had fewer taxpayers and an increasing average tax burden until 2010. From 2010, the personal income tax system was basically restructured, as against the former years, fewer people avoided taxes due to the lower tax rates and lower social insurance burdens and due to the family-child support (which is well above the average wage), so thus they could legally reduce the amount of tax.

The introduction of the single rate tax system did not promise a clear turnaround but if we look at the trend in the number of taxpayers and the number of per capita burdens on the taxpayers, we can see that it fulfilled the expectations that had, in fact, not been anticipated.

\section{Acknowledgement}

Some parts of the paper have been presented at the Third International Scientific Conference - ITEMA 2019 (http://www.itema-conference.com).

\section{References}

Antal, L. (2004). A 90-es évek magyar gazdaságpolitikája. in: J. Veress (Ed.) Fejezetek a gazdaságpolitikából., Budapest: Aula Kiadó

Atkinson, A. B., \& Stiglitz, J. E. (2015). Lectures on Public Economics: Updated Edition. Princeton University Press. 
Oates, W. E. (1985). Searching for Leviathan: An empirical study. The American Economic Review, 75(4), 748-757.

Brennan, G., \& Buchanan, J. (1985). Searching for Leviathan: An empirical study. The American Economic Review, 75(4), 748-757.

Constitutional Court (1995) Decision 43/1995. p. 1995/188

http://public.mkab.hu/dev/dontesek.nsf/0/17D9A8FD9202EEFEC1257DCD00399438? OpenDocument

Complex CD Jogtár (2006). Határozat jogszabály alkotmányellenességének utólagos vizsgálatára irányuló indítványok,valamint mulasztásban megnyilvánuló alkotmányellenesség megszüntetésére indított hivatalból indított eljárás alapján”. Budapest. https://net.jogtar.hu

Estévez Schwarz, D., \& Sommer, E. (2020). Feasible smooth income tax schedules: benefits and distributional implications. Applied Economics, 52(2), 175-194. Doi: http://doi.org/10.1080/00036846.2019.1638500

Ékes, I. (1997). Adózás 1988-1996. Központi Statisztikai Hivatal, Statisztikai Elemzések. Ékes,I. (1993). Adózás 1988-1996. Statisztikai Szemle 1997(1-2), 45 -57.

Forte, F., \& Peacock, A. T. (1981). Tax planning, tax analysis and tax policy. In The Political Economy of Taxation. Basil Blackwell Oxford.

Gulácsi,G. (1993). A személyi jövedelmek helyi adóztatása, illetve a személyi jövedelemadó, mint a helyi önkormányzatok bevétele. in: A. Semjén (Ed.) Adózás, adórendszerek, adóreformok. Szociálpolitikai Értesítő 1993(1-2), Budapest: MTA Szociológiai Intézet, 436-474. http://realj.mtak.hu/7849/1/MTA_SzocPolErtesito_1993.pdf

György, L., \& Veress, J. (2016). The Hungarian economic policy model after 2010. Public Finance Quarterly, 61(3), 360-381.

Haufler, A. (2001). Taxation in a global economy: theory and evidence. Cambridge University Press.

Hetényi, I. (2006). Az adórendszer fejlõdésének tendenciái az OECD-országokban. Pénzügyi Szemle 51(1), 3-22.

Kádár, B. (2000). Globalizációs kihívások - gazdaságpolitikai válaszok. Társadalom és gazdaság Közép-és Kelet-Európában/Society and Economy in Central and Eastern Europe, 22(2), 7-23.

Kalaš, B., Mirović, V., \& Milenković, N. (2018a). The relationship between taxes and economic growth: Evidence from Serbia and Croatia. The European Journal of Applied Economics, 15(2), 17-28. Doi: https://doi.org/10.5937/EJAE15-18056 
Kalaš, B., Mirović, V., \& Andrašić, J. (2018b). Empirical analysis of value added tax and inflation rate: Tuckey's HSD test in selected Western Balkan countries. Ekonomika, 64(2), 99-109. Doi: https://doi.org/10.5937/ekonomika1802099K

Kramer, D., Čok, M., Cirman, A., \& Verbič, M. (2016). Switching personal income tax and social security contributions between Slovenia and the Federation of Bosnia and Herzegovina. Economic research-Ekonomska istraživanja, 29(1), 682-695. Doi: https://doi.org/10.1080/1331677X.2016.1193948

Ministry of Finance. (1994). Az adók és a föbb makrogazdasági mutatók viszonya. Budapest: Ministry of Finance

Ministry of Finance. (2001). Az adók és a főbb makrogazdasági mutatók viszonya. Budapest: Ministry of Finance

MSZOSZ. (2012). Az egykulcsos személyi jövedelemadó hatásai.Budapest. MSZOSZ. www.liganet.hu > news

Magyar Közlöny. (1986). Personal Income Tax Act. 1987. évi VI. Törvény a személyi jövedelemadóról. Magyar Közlöny, 1986 (27) 1267-1324.

Peacock, A. (1997). Public choice analysis in historical perspective. Cambridge University Press. Rowley, C. K. (1993). Public Choice Analysis in Historical Perspective.

Stiglitz, J. E. (2002). New perspectives on public finance: recent achievements and future challenges. Journal of Public Economics, 86(3), 341-360. Doi: https://doi.org/10.1016/S0047-2727(01)00193-1

Szigeti, S. (2007). Az Egészségbiztosítási Alap pénzügyi instabilitásának okairól. Interdiszciplináris Magyar Egészségügy / Journal of Hungarian Interdisciplinary Medicine, 6(2), 9-17.

Urban, I., Čok, M., \& Verbič, M. (2019). The burden of labour taxation in Croatia, Slovenia and Slovakia in the period 2011-2017. Economic research - Ekonomska istraživanja, 32(1), 1430-1456. Doi: https://doi.org/10.1080/1331677X.2019.1638291

Varian, H. R. (2014). Intermediate Microeconomics: A Modern Approach: Ninth International Student Edition. New York: W.W. Norton \& Company.

Veress, J. (2004). A gazdaságpolitika szerepe a modern gazdaságokban. in: J. Veress (Ed.) Fejezetek a gazdaságpolitikából, Budapest: Aula Kiadó, 13-49. 